\title{
Clínica psicanalítica da língua: vias associativas interlinguísticas, tradução e transferência
}

\author{
Psychoanalytical approach of language: Interlinguistic \\ association paths, translation and transference
}

Thamy AYOUCH ${ }^{1,2}$

\begin{abstract}
Resumo
A clínica da língua corresponde aqui ao trabalho com pacientes plurilíngues ou poliglotas, recebidos em país estrangeiro, no caso a França. Questiona-se sobre os mecanismos conscientes e inconscientes que se ativam na passagem da língua nativa à língua adotada na terra de acolhimento, e sobre os mecanismos simétricos que podem ter lugar quando a sessão se passa na língua nativa. Trata-se aqui de refletir sobre a função da tradução linguística e psíquica, na sessão analítica e na transferência. Por meio de ilustrações clínicas, abordam-se os modos de relacionamento do sujeito com a língua materna, bem como a sedimentação de camadas de línguas para os poliglotas.
\end{abstract}

Palavras-chave: Multilinguismo; Psicanálise; Tradução; Transferência (Aprendizagem).

\begin{abstract}
Clinical approach of language here refers to clinical experience with plurilingual and polyglot patients attended to in a foreign country (France). The aim is to question the conscious and unconscious mechanisms activated when shifting from native to foreign language and the symmetrical mechanisms when the psychoanalytical session is in the patient's native language. This article deals with the function of linguistic and psychic translation in psychoanalytical session and in transference. Through various clinical illustrations, the author tackles the relationship to mother-tongue, and the multi-layered language of polyglot and plurilingual subjects.
\end{abstract}

Keywords: Multilinguism; Psychoanalysis; Translation; Transference (Learning).

É comum ouvir dizer, na prática psicanalítica, que não se atinge a língua do inconsciente sem passar pela língua materna. Além da necessidade de acertar o sentido da metáfora de língua do inconsciente, serão os processos primários conce- bíveis como língua? Trata-se aqui da questão da possibilidade de praticar a psicanálise ou a psicoterapia numa língua distinta da língua materna do/a paciente. Essa questão surge eminentemente com pacientes multilíngues ou poliglotas, atendidos em

\footnotetext{
$\nabla \nabla \nabla v$
}

1 Université Charles de Gaulle - Lille 3, UFR de Psychologie, Domaine Universitaire du Pont de Bois, BP, 60149 59653, Villeneuve d'Ascq Cedex, France. E-mail: <thamy.ayouch@gmail.com>.

2 Universidade de São Paulo, Instituto de Psicologia. São Paulo, SP, Brasil. 
contextos linguísticos e culturais distintos dos nativos.

Tanto para o/a paciente quanto para o/a analista, haverá aqui um movimento de circulação entre línguas, e em quê consistiria esse processo? Em que idioma far-se-ia a concatenação das associações pelo/a paciente poliglota ou multilíngue, e pelo/a analista que o/a atende?

Em Paris, em um centro de atendimento de migrantes oferecendo polos linguísticos diversos, mas também na clínica privada, pude acompanhar pacientes estrangeiros instalados na França. Isso me deu a oportunidade de fazer um trabalho psicoterapêutico com pacientes hispanófonos, italófonos, lusófonos, anglófonos e arabófonos, no contexto linguístico francófono de Paris.

Questionei-me sobre os mecanismos conscientes e inconscientes que se ativavam na passagem da língua nativa à língua adotada na terra de acolhimento, e sobre os mecanismos simétricos que podem acontecer quando a sessão se passa na língua nativa. Perguntei-me sobre essa tradução interlinguística e a conversão sintomática: a tradução linguística, imposta ao estrangeiro que chega a um país, é acompanhada de uma tradução dos processos inconscientes, transformando elementos inconscientes em sintomas? Reciprocamente, a des-tradução efetuada pelo/a terapeuta que recebe o/a paciente na língua nativa seria comparável à tradução-interpretação da psicanálise?

E, ampliando o foco da questão, qual é a função e o sentido do multilinguismo e do poliglotismo na psique do/a analisando/a, e nas interações com o/a analista? Há vias de associação específicas aqui? Como se articulam as associações da dupla analista-analisando/a, durante a sessão clínica?

Pelos multilíngues, que vêm falando várias línguas desde a infância, o mundo é construído sobre a associação de palavras plurais às coisas, e de uma pluralidade de redes de "representações de palavra" ligadas a uma única rede de "representações de coisa". Os poliglotas, aliás, ao aprender quando adultos novas línguas, acrescentam ao seu patrimônio linguístico uma nova rede: integram 98 simultaneamente as duas redes.
O presente trabalho não pretende dar conta de forma precisa e detalhada de casos atendidos, mas abordar a questão do uso da língua materna na sessão analítica e psicoterapêutica, seja pelo/a analisando/a ou pelo/a analista. Trata-se aqui de refletir sobre a função da tradução linguística e psíquica na sessão analítica, e na transferência. Após analisar modos de relacionamento do sujeito com a língua materna, este trabalho abordará a sedimentação de camadas de línguas para os poliglotas, para então focalizar a questão da tradução linguística relacionada com a tradução psíquica e a transferência.

\section{O afastamento da língua materna}

Para aqueles pacientes que, ao chegarem a um novo país, têm que falar uma nova língua, parecia-me importante levar em conta esse outro exílio na nova língua. Achava que, ao se precipitar em um contexto onde se deve falar a língua do outro, o sujeito migrante se encontrava em um dramático entre-duas-línguas, perto da materialidade da palavra, porém longe do sentido. Imaginava que, perante esse outro que parecia especialmente tagarela e se obstinava a utilizar fonemas inúteis, perante essa massa sonora afastada do seu significado, o/a estrangeiro/a vivia uma extrema solidão, um grande abandono. Essa confrontação com uma nova língua, ainda mais quando ela não é conhecida, conscientiza muitas vezes da falta de motivação tanto na língua de acolhimento como na língua de origem.

Eu me lembrava de Hassoun (1993), dizendo que "o exílio começa quando a língua ou o dialeto falados pelos antepassados são esquecidos, murmurados na vergonha ou no gozo". Portanto, em uma onipotente fantasia de reparação, imaginava que só uma terapia no idioma nativo poderia permitir uma restauração narcisista desses deportados da língua.

A prática clínica com pacientes estrangeiros me levou a ver que esse não era necessariamente o caso. Embora haja um exílio entre duas línguas, uma barreira adicional na realidade psíquica, a nova língua é com frequência investida de uma maneira 
que apazigua a realidade psíquica, e afasta um sexual-infantil que seria temível se aparecesse na língua materna.

O exílio na língua é próprio a qualquer criança que aprende a falar: está construindo, na sua própria língua, representações de palavra sobre representações de coisa, mas as primeiras, conscientes, nunca cobrem totalmente as segundas, inconscientes. Na sua própria língua, a criança é estrangeira. A língua, composta de representações de palavra, permite nublar, velar as representações de coisa, evitando assim um contato direto demais, alucinatório, com as coisas. A intrusão de uma outra língua torna arbitrária essa dissimulação, e fragiliza a possibilidade da língua nativa velar as coisas. Estas surgem então na selvageria da sua estrangeiridade, unheimlich, desconhecidas/reconhecidas, como em um pesadelo. Por conseguinte, cabe ressaltar que, se o inconsciente é a língua estrangeira de todos, o/a estrangeiro/a, ao ser confrontado/a com uma nova língua, vive novamente essa estrangeiridade. Contudo, a nova língua pode também permitir um novo velamento das coisas, como na experiência da criação poética, quando o/a poeta/isa desmonta a relação rígida entre significado e significante e instila à língua uma nova vida.

Nesse sentido, no atendimento a pacientes estrangeiros, fui confrontado com uma clínica da "revitalização" da língua nativa pela língua estrangeira, quando os pacientes recorriam à língua estrangeira para se reconstruir psiquicamente, e afastar o arrombamento da língua materna. Para o/a multilíngue ou o poliglota, a nova língua permite evitar a invasão de um trecho da língua materna fortemente investido. Ela favorece assim uma reparação de representações sexuais-infantis. A terapia aspira a estabelecer um vai-e-vem entre língua materna e nova língua, para permitir um acesso mais apaziguado a essas vivências da sexualidade infantil.

É o que testemunhei com muitos pacientes, como Malek, um marroquino de 22 anos que tinha chegado à França 5 anos antes eu atendê-lo. Sua mãe tinha ficado no Marrocos, e seu pai se movia entre os dois países. Era escolarizado em uma fundação que acolhia jovens em dificuldades, dando-Ihes uma formação profissional. Ele não apresentava nenhuma ruptura de contato com a realidade nem dissociação. Porém, estava vestido de modo incomum (superposição de roupas), manifestava dificuldades de compreensão, e tinha uma linguagem analógica paradoxal (sorria quando falava de problemas, ou ficava totalmente impassível frente a chistes ou encorajamentos). Além disso, não manifestava qualquer fluidez em suas associações, muitas vezes ficava sem palavras, e apresentava muitos mecanismos defensivos de aspecto obsessivo, como o isolamento, o isolamento afetivo, a formação reativa, a denegação, mas também algumas recusas.

A primeira entrevista foi tensa, vaga e superficial. Tive a impressão de que havia uma língua comum entre nós, destinada a evitar qualquer comunicação. Suas primeiras palavras referiam-se ao tempo, e ele se retirou para trás de uma fórmula bem reservada e genérica: "É melhor que não esteja quente demais, nem frio demais". Seguia expressando-se por essas fórmulas muito educadas e vagas. Quando lhe disse que a entrevista podia acontecer em árabe se ele quisesse, recusou educadamente. Não elaborava nenhuma demanda psíquica, tanto que fora enviado ao centro por um psiquiatra. Referia que seu único problema eram os documentos de residência na França como estrangeiro, o que não Ihe permitia encontrar um estágio condizente com sua formação profissional. Até esse problema era diluído em uma fórmula ontológica geral: "Não se pode não ter problemas. Todos temos problemas, e ninguém é perfeito. Só Deus é perfeito". Sob o francês bem dominado, brotava a generalidade de fórmulas religiosas marroquinas, e o tabu cultural consistindo em excluir qualquer argumento que implique o risco de sacrilégio - "quem poderia se assimilar a Deus?", ele expressava, em uma mistura de fantasia e proibição.

Quando perguntei sobre suas relações familiares, seus irmãos, sua mãe, respondeu que sentia pouca falta desta, e negou qualquer forma de relação de intimidade com ela, afirmando que "uma mãe tem que amar igualmente todos os filhos". Disse que não tinha nenhuma lembrança da sua infância. Não sentia falta do país que não visitou durante quatro anos, e concluiu com uma nova frase 
impessoal: "Não posso preferir o Marrocos à França, já que cada um é diferente". Era como se o uso do francês por esse paciente permitisse não ir além desse nível de generalização e de negação de qualquer posição subjetiva preferencial, e viesse reforçar uma dificuldade de simbolizar.

As sessões posteriores foram mais brandas, mas ele seguiu usando o francês para estabelecer uma distância entre nós, e se proteger de representações pessoais demais que o árabe podia despertar. Quando, às vezes, recorria a essa língua, era para se defender de acusações que outros poderiam ter feito contra ele : "Eu não era مفشش \{mfechech\}" (mimado demais), "Não se deve ser اناني \{anani\} (egoísta)", negando assim qualquer singularização ou subjetivação.

Minha hipótese era que sua resistência a falar árabe agia como uma proteção contra sensações não elaboradas e não simbolizáveis, e que a nova língua funcionava como um mecanismo de defesa, reforçando o isolamento psíquico e a dificuldade de simbolizar. Evidentemente, não ia forçá-lo a falar árabe: a escolha da língua é sempre feita pelo paciente. Todavia, meu trabalho consistia em tentar favorecer uma circulação entre as duas línguas, escutando, sob o francês, uma estrutura associativa em árabe. O trabalho terapêutico aspirava a revalorizar a língua materna como bom objeto e a reativar certos aspectos dela, mas despojando-os da carga afetiva ameaçadora.

Achava que a ideia obsedante acerca dos documentos de residência, além da dimensão de um risco concreto, era ambivalente. Enquanto ele não tivesse documentos, não podia viajar para o Marrocos, o que the fornecia o gozo de escapar ao desejo da mãe e ao sentimento de culpa por abandoná-la.

Tratava-se, portanto, de tentar ver o que, na circulação entre as duas línguas, poderia superar esse bloqueio das associações, essa paralisia da simbolização, e figurar sensações corporais ainda não elaboradas psiquicamente. Aqui, a figuração do afe- to foi o objetivo essencial: tratou-se de providenciar, nas "imagens autóctones" do analista, um material sensorial, encarnado, corporal, suscetível de traduzir aquilo que nunca recebeu forma nem figuração no analisando. Tratou-se de providenciar palavras, resgatando vivências corporais não figuradas, ampliando sua capacidade sensorial.

A transferência, visando aqui o surgimento de afetos e sensações não integrados, recorreu a vivências corporais e mobilizou a presença encarnada tanto do analisando como do analista.

Foi quando uma viagem associativa teve lugar na sessão seguinte. Ele contou como os seus camaradas às vezes o chamavam de gafanhoto. Sem transição, evocou imediatamente depois a cantina da escola e as comidas salgadas demais. Escutando-o, deixei-me levar por associações de ideias e de sensações, talvez ecoando as dele, e me lembrei de rimas infantis em árabe que poderia traduzir assim:

$$
\begin{aligned}
& \text { Gafanhotinho salgado, } \\
& \text { por onde você passou, } \\
& \text { o que comeu e o que bebeu } \\
& \text { Ó mestre Bouzekri, } \\
& \text { Depressa cozinhe o meu pão... }
\end{aligned}
$$

Seguindo o curso de minhas associações, lembrei de um jogo de infância quando meu pai nomeava cada um dos meus dedos e lhes atribuía uma função ("o primeiro vai ao mercado, ou outro cozinha o seu pão", etc.). Também resgatei sensações de um outro jogo no qual meu pai percorria o meu braço, dos dedos até o pescoço, para me fazer cócegas, e pronunciava em árabe palavras ainda enigmáticas para mim, descrevendo o movimento de um rato comendo um ovo e logo uma oliva. Em uma concatenação interlinguística, lembrei de rimas infantis francesas sobre um rato verde que se transformava em caracol${ }^{3}$. Perguntei então a Malek se conhecia rimas francesas, e the contei a do rato verde. Ficou interessado, e apontou a falta de lógica desse rato virando caracol. Respondi que, pelos óculos humanos, havia poucas diferenças

$\boldsymbol{v} \boldsymbol{v} \boldsymbol{v}$

3 O texto das rimas em francês é: "Une souris verte / qui courait dans l’herbe, / je l'attrape par la queue, je la montre à ses messieurs / ces 100 messieurs me disent / trempez-la dans l'huile, trempez-la dans l'eau, ça fera un escargot tout chaud". 
entre esses animais pequenos, ratos, caracóis, insetos. "Como os gafanhotos?" perguntou. E começou a recitar as rimas infantis marroquinas do gafanhoto com pão. Fiquei assombrado pelo mimetismo das nossas associações.

Assim, nessa regressão linguística das rimas onde as palavras árabes, embora próximas do sexual-infantil, não eram temíveis, ele se autorizou a falar do contexto onde a mãe lhe cantava as rimas, e seguiu associando. Ele se expressava em francês, mas pontuava o discurso por algumas palavras árabes - الدراري \{edrari\} (as crianças), الخبز \{elhobz\} (o pão), باش ننعس \{bach nen'ass\} (para que dormisse).

Nas sessões posteriores, Malek se permitiu recorrer mais a palavras em árabe. Recordou a última ligação telefônica à mãe, e a emoção materna. Seus mecanismos de defesa pareciam menos rígidos: as representações eram menos isoladas, as associações mais fáceis.

Interroguei-me sobre o que teria acontecido. Por trás das suas palavras francesas, tinha surgido uma rede de associações sensíveis, sensoriais, em árabe, que escutei e dupliquei com as minhas próprias associações. As representações de palavra, traduzidas, sem ele saber, na transição em francês do gafanhoto ao sal, puderam indiretamente dar lugar a uma figuração de sensações e afetos. Por uma nova tradução, através das minhas associações e de algumas rimas francesas, pudemos fazer surgir novas representações de coisa dele, mais apaziguadas. Clinicamente, o trabalho realizado aqui, ao invés de considerar apenas associações de ideias, incluiu, através dessa circulação interlinguística, as associações de sensações, implicando a relação com o corpo tanto do paciente como do terapeuta.

\section{A reparação da língua materna}

O recurso a uma nova língua também permite, de um modo diferente, efetuar uma reapropriação da língua materna, através de um verdadeiro trabalho de reparação do que pode ter sido traumático para a língua materna. Pude acompanhar uma criança no seu trabalho de revitalização e cura da língua materna através da língua estrangeira.

Adriana tinha cinco anos, e fazia oito meses que tinha chegado à França com a mãe, uma refugiada política angolana. Nas confrontações violentíssimas da União Nacional para a Independência Total de Angola (UNITA) e do Movimento Popular de Libertação de Angola (MPLA), milicianos invadiram sua casa e, diante dela, mataram o pai, violaram a mãe e estrangularam os dois irmãos gêmeos, ainda bebês. Adriana só se salvou porque a mãe disse "Não é minha filha, é filha dos vizinhos". Em um mimetismo total, do mutismo à roupa e ao penteado, mãe e filha manifestavam o mesmo traumatismo silencioso.

Gradativamente, o trabalho das sessões se orientou na direção de uma identificação dos membros do corpo através do desenho, da pintura e de jogos com água. Os primeiros desenhos não apresentavam cores, os personagens não tinham pescoço. Nessas primeiras sessões, eu tentava comentar tudo o que fazíamos em português, mas a menina se recusava a falar.

Foi através do francês, progressiva mas rapidamente aprendido na escola, que Adriana pôde sair do mutismo, de uma forma bilíngue. Começou a comentar seus desenhos usando o francês, logo acompanhando cada palavra francesa com uma portuguesa. Numa paisagem de "maisons-casas" apareciam "papillons-borboletas" e "rivières-rios" onde navegavam "bateaux-barcos" dirigidos por "frères-irmãos". Pouco a pouco, Adriana aplicou essa dupla linguagem a seu corpo, composto de "cou-pescoço", "bras-braços", "cheveux-cabelos". Por uma associação interlinguística, à medida que investia o corpo ("le corps"), apareciam cores nos seus desenhos ("cor" e "corps" sendo homônimos, em português e em francês).

Através dessa identificação dupla, do francês ao português e vice-versa, a língua de acolhimento veio repetir, confortar, sustentar e reparar a língua materna traumatizada. A criança só pôde evocar Angola ao passar do português ao francês.

A identificação com a mãe tornou-se então menos patológica. A criança começou a se diferen- 
ciar na roupa e no penteado, à medida que manifestava uma fluidez psíquica. Não ser, como tinha afirmado a mãe, a filha da sua mãe para poder sobreviver exigia uma identificação massiva para não se derrubar. A falta de filiação apresentava a alternativa a ser abandonada pela mãe ou morrer. Com o apoio do francês, Adriana pôde dizer "maman" para melhor dizer "mãe", e assim reparar a língua materna.

Mas o que é a língua materna? No uso comum, a primeira língua falada por uma criança é sempre associada a uma dimensão materna em muitas línguas (Muttersprache. mother-tongue, lengua materna, madre língua, لفة الام Slughat el um\}, ספת אם \{sefet im\}). Porém, segundo a definição de muitos dicionários, não há relação necessária entre essa primeira língua e a mãe. Existem "vice-mães", e a língua materna é também a língua das pessoas que aparecem e desaparecem do cenário psíquico da criança pronunciando as suas primeiras palavras. A língua materna é a língua veiculada pela mão ou a pessoa em posiçao de mãe que permite à criança se separar dela, articular uma demanda sem temer ser engolida em um "sim" massivo que antecipa seus desejos ou em um "não" que os anula. Para não ser mortífera, essa língua tem que marcar uma distância, conjugar o familiar e/ou estrangeiro.

A língua materna é aquela que confronta o desejo da mãe e torna o sujeito louco se é animada pelo mito de unicidade. O uso de uma nova língua na sessão clínica permite às vezes descerrar aquilo que se fechou na língua materna, assimilando língua e imago ameaçadora da mãe.

\section{Poliglotas e palimpsestos}

Na clínica da língua surgem também outros destinos linguísticos, como é o caso de poliglotas e multilíngues, em que é constante a presença de outras línguas sob a língua falada, perceptíveis a partir de uma rede de associações. Quando um sujeito multilíngue ou poliglota se expressa numa língua, os outros idiomas estão "em sofrimento" por baixo dela, no duplo sentido de espera e dor.

Para muitos pacientes estrangeiros, o francês

102 ressoa sob sua língua nativa, modificando-a, provo- cando "galicismos". Uma paciente peruana atendida em espanhol, e que dizia não poder falar francês produzia, por exemplo, palavras como: "parlar" (contaminação do espanhol "hablar" pelo francês "parler"), "responder al teléfono" (contaminação de "contestar el teléfono" por "répondre au téléphone"), "disputirse" (contaminação de "discutir" por "se disputer"), "sufrenza" (contaminação de "sufrimiento" por "souffrance"), ou até, numa verdadeira conversão histérica: "quiero exprimir mi dolor" ("exprimir" quer dizer espremer, e é bem diferente de "expresar", aqui contaminado pelo francês "exprimer sa douleur").

Entretanto, a presença de várias camadas linguísticas nas concatenações associativas pode chegar a ser ainda mais sutil. Atendi uma paciente anglófona que manifestava em suas associações uma dupla língua inconsciente. Joan era uma romancista australiana de 39 anos, instalada em Paris fazia dois anos, depois de ter vivido 15 anos em Girona, uma cidade catalã da Espanha. Filha de mãe ucraniana e pai alemão, não falava russo mas compreendia alemão, e considerava a sua estada na Europa como uma volta às origens. Todavia, ao se instalar na Espanha e em seguida na França, escolheu reescrever o romance familiar em línguas estrangeiras. Joan compreendia o francês, mas preferia se expressar em inglês. Veio consultar-me por seus ataques de pânico e por problemas conjugais. Tinha dificuldades em compreender François, que namorava havia nove meses, perguntando-se se não haveria uma divergência de códigos culturais.

A primeira sessão, em inglês, tratou imediatamente do assunto da língua. Ela me disse "You really sound British, don't you?" ("Você fala com um sotaque muito inglês"), e me explicou que foi escolarizada em uma instituição privada em Melbourne, onde o sotaque inglês é um sinal de boa educação. Sua observação me fez sorrir e estabeleceu diretamente um contexto multilíngue entre nós. Minhas associações me levaram a Barcelona quando, em companhia de um amigo inglês, falamos com uma turista inglesa. Esta nos perguntou se éramos ingleses, ele disse sim e eu não. A turista me respondeu "Yes indeed, I'm afraid you don't 
look English" ("temo que você não pareça inglês"). Repliquei, quase sem refletir "Well I'm afraid you do" ("temo que você sim, pareça inglesa"). Ao me fazer recordar de Barcelona, instalou-se entre Joan e mim um contexto espanhol e catalão.

Considerando a angústia dos ataques de pânico como afeto desconectado da sua representação, e precisando ser qualificado, perguntei a Joan quando aconteciam os ataques. Ela disse ter identificado algumas situações desencadeadoras dos ataques de pânico, tais como quando atravessava uma ponte, quando alguém ameaçava ir embora subitamente, ou quando se lembrava das brigas entre seus pais. Todavia, na Espanha, novas situações tinham surgido: sofreu um ataque de pânico visitando o "Barrio Chino" de Barcelona. Um ano depois, teve uma angústia semelhante ao chegar a Sabadell, uma cidade perto de Barcelona. Mais uma vez sentiu pânico quando estava atravessando um campo e, inexplicavelmente, quando o filho de uma amiga brincava com um barbante. Em Paris, evitando as pontes, tinha vivido um ataque de pânico só uma vez, ao brigar com o namorado. Ela não compreendia por que tinha pânico em contextos tão diversos.

Na sessão preferia o inglês, insistindo que somente essa língua Ihe permitia expressar completamente os seus sentimentos, e enumerando os problemas que teve ao se instalar em outros países estrangeiros. Também designava tanto sua apreciação por certas palavras quanto sua aversão por outras. Por exemplo, detestava as palavras que acabavam com os fonemas [dl], como "saddle", "griddle", "noodle" e "cradle".

Numa sessão ulterior, ela narrou o ataque de pânico que teve quando brigou com o namorado. Ela Ihe tinha dito "I don't like playing second fiddle" ("não gosto dos segundos papéis"). Quando Ihe perguntei quem dizia essa frase, respondeu que era sua mãe quando brigava com seu pai. E repetiu a frase imitando um sotaque russo.

Depois dessa sessão, tentei fazer uma resenha do que tínhamos conversado em vários encontros, transcrevendo momentos das sessões, sem procurar lembrar a ordem exata, mas seguindo minhas associações livres. Escrevi alguns elementos que Joan tinha me contado, e também palavras, "saddle", griddle", "noodle", "cradle", "fiddle". Parecia muito provável que o som [dl] fosse ligado a "second fiddle". Ressoava em minha cabeça a frase da mãe que Joan tinha pronunciado com sotaque russo. Também escrevi a anedota com a inglesa em Barcelona e por ter morado lá e pensado em meus amigos catalães, segui escrevendo em catalão. Transcrevi os momentos de pânico, "ponts" (pontes), "abandó" (abandono), "discussió" (briga), "Sabadell", "bordell" (o "Barrio Chino" tendo sido o bairro da prostituição), "pradell" (campo) e "cordell" (barbante). A rede de associações parecia irradiar desde o significante "fiddle", ligado aos outros pelo fonema final [dl], que se pronunciava em catalão quase como um [dl] russo. Quando esse significante estava conscientemente identificado, o afeto sentido era aversão - Joan odiava as palavras cuja terminação era [dl]. Quando, porém, esse fonema só sustentava, quase inconscientemente, outras palavras, a partir de uma outra língua, o afeto se desfazia de sua representação, ficava livre, desqualificado, e se transformava em angustia profunda. Às vezes Joan pensava em catalão.

Freud exemplifica esse tipo de rede associativa, onde uma língua infiltra as representações de outra, no texto sobre o fetichismo. O alemão "Glanz auf der Nase", brilho sobre o nariz, de que falava o paciente, revelou-se como um "Glance" (inglês), olhar.

Outras redes associativas surgiram nas sessões posteriores. Joan se pôs a falar de pontes para elaborar a angústia dos ataques de pânico. Seguiu associando: "Bridge - bridge the gap - gap" ("ponte - reunir, agrupar - vazio"). As brigas entre seus pais eram o que impedia "bridge the gap" entre eles. Mas tinha um "gap", um grande vazio que provocava os ataques de pânico. Na Catalunha, Joan tinha lembrado uma cena de briga entre seus pais, quando o pai tinha tentado matar a mãe. Joan descreveu a cena em detalhes, recordando até as cores das roupas que seus pais vestiam, mas se justificou dizendo que não podia fazer nada, pois era apenas uma criança.

Essa abundância de detalhes me fez pensar em uma lembrança encobridora. Depois de trans- 
crever a sessão, eu me dei conta de que, mais uma vez, suas associações podiam ter sido interlinguísticas. O significante horrível do vazio, sem figuração possível, "gap" , tinha infiltrado a lembrança, para tentar figurar o que não tinha nenhuma representação. Mas era em catalão. Joan situava essa cena na idade de oito anos, vuit em catalão, que se pronuncia da mesma forma que buit, o vazio.

O surgimento da angústia característica dos ataques de pânico corresponde, a meu ver, a uma busca de figurabilidade do afeto que acede à consciência, dissociado de sua representação. Na metapsicologia freudiana, a pulsão tem dois representantes: o representante-representação (Vorstellungsrepresentanz) e o afeto. Quando consciente, o afeto é a coloração afetiva de uma situação, uma qualidade apreensível pelo ego. Quando inconsciente, é um processo energético de tensão e descarga, na base dos movimentos somatopsíquicos inconscientes.

Uma representação pode ser segmentada, e os processos primários podem concernir somente a uma parte dela. O afeto, ao contrário, não se decompõe com o recalcamento. Sendo a finalidade do recalcamento evitar o desprazer, o destino do afeto se revela mais importante que o da representação. Esse destino pode ser uma repressão total, uma manifestação sob uma coloração afetiva qualquer, ou sua transformação em angústia (Freud, 1915/1968).

No outro sentido, antes do recalcamento acontecer, partindo do inconsciente para chegar à consciência, o afeto pode ser considerado como movimento de uma pulsão em busca de figurabilidade. Aqui, Freud descreve dois destinos do afeto: em uma concepção "arrombadora", na qual o afeto chega diretamente do sistema inconsciente à consciência, sempre aparece uma angústia, afeto contra o qual todos os afetos suprimidos são intercambiados. Numa concepção vicariante, o afeto se desenvolve a partir de uma representação substitutiva que a pulsão encontra no consciente. Se a concepção vicariante caracteriza uma grande parte dos mascaramentos e ocultações próprios à neurose, a concepção arrombadora é que define, a meu 104 ver, a irrupção do afeto nos movimentos de angústia enquanto falta de simbolização e psiquização. Foi interessante ver aqui que essa busca de figurabilidade do afeto arrombando a consciência se fez através de redes de representações de palavra interlinguísticas. $\mathrm{O}$ afeto nu do ataque de pânico irrompe em ocasiões apresentadas por significantes disfarçados através de associações e traduções interlinguísticas.

Esse processo de uma segunda língua por trás da língua principal é notavelmente descrito por Abraham e Torok (1999). Para compreender essa paciente multilíngue, era preciso buscar em inglês e russo o sentido do que ela dizia em alemão.

Para concluir o relato e meus encontros com essa paciente, acrescento que ela também gostava de brincar com versões diferentes de seu nome. "Joan" não existia como nome nem na Espanha nem na França - os franceses confundem com "John", o que aumentava os jogos com sua sexuação. Portanto, fazia-se chamar Joana pelos catalães, Juana pelos hispanófonos e Jeanne pelos franceses. Como Fernando Pessoa e seus heterônimos, Joan assinava publicações diferentes - romances, novelas, poesia e crítica literária -, com diversos nomes. Compreendi que Joan aceitava ser ao mesmo tempo Jeanne, Joana e Juana quando disse que havia finalizado a sua tese sobre literatura, incluindo no manuscrito uma parte ficcional.

\section{Tradução linguística e tradução psíquica}

Tentemos agora analisar, nesse tipo de associações multilíngues, a função da tradução interlinguística e da tradução psíquica. A noção de tradução é central na teoria freudiana, estando presente em dois termos, Übertragung e Übersetzung. Dois processos globais recíprocos são descritos de forma recorrente como traduções. De acordo com o primeiro, a fonte é o inconsciente, e o resultado os efeitos do inconsciente: sonhos, lapsos, atos falhos ou sintomas. Essa tradução-codificação liga os restos mnêmicos, as representações de coisa e as representações de palavra. Ela procede no sentido inverso ao recalcamento. No outro sentido (da consciência ao inconsciente), pela tradução-interpretação, durante a sessão, os efeitos do inconsciente são a 
fonte, enquanto os pensamentos inconscientes são a meta. Essa tradução segue o curso do manifesto ao latente.

Trata-se aqui de uma demanda de tradução, esta que se coloca por esses pacientes multilíngues ou poliglotas? Seria possível comparar por um lado a tradução entre línguas e, por outro, a tradução dos processos do inconsciente evocada por Freud? Serão ambos os processos meramente linguísticos?

Como comenta Benjamin (2000), o/a tradutor/a pode se achar em um momento de suspensão inter-linguística e transitar por um estado fora da língua. Similarmente, o/a analisando/a se coloca às vezes num limbo intersemiótico, separando a interpretação da linguagem do sonho ou do sintoma. Contudo, se o/a tradutor/a, ou o/a locutor/a estrangeiro/a, passa por esse estado de Unheimlichkeit, onde os significantes da língua de origem e da outra língua parecem pouco naturais, é porque o fenômeno de tradução interlinguística convoca processos do inconsciente. Não são as traduções entre sistemas psíquicos que manifestam caracteres da tradução linguística, mas, ao contrário, é esta que procede do inconsciente.

Há, efetivamente, uma semelhança entre os processos do inconsciente e as deformações efetuadas sobre um texto pela tradução. Na passagem de uma língua à outra, têm lugar várias operações, como figuras de racionalização, passagem da polissemia à monossemia, enriquecimento e empobrecimento quantitativos, homogeneização, destruição das locuções. Essas operações caracterizam também a passagem dos processos primários aos secundários, na tradução-codificação. No outro sentido, as operações de alongamento ou empobrecimento qualitativo, de destruição dos ritmos, parecem corresponder a processos de tradução-interpretação, que desdobra as condensações do sonho e cancela seu caráter icônico e seu ritmo pela elaboração linguística.

Todavia, na tradução psíquica, não há língua original nem língua final. Os sistemas psíquicos não são línguas, mas, antes, lugares de inscrição. Não existe uma língua dos processos secundários que seja independente desses processos: representações de palavra, imagens de sonho, traços mnêmicos superiores. Ao contrário, uma língua não se reduz às suas traduções. $\mathrm{O}$ espanhol, por exemplo, não se reduz à tradução das Mémoire d'Hadrien de Marguerite Yourcenar por Julio Cortazar, ou à tradução do Livro do desassossego de Pessoa por Angel Crespo.

Simetricamente, não existe uma língua-fonte dos processos primários, salvo na fantasia de uma língua originária, materna, irremediavelmente perdida, e esses processos são acessíveis só em sua tradução psíquica.

Por conseguinte, na tradução-codificação, como na tradução-interpretação, não há uma língua-fonte que seja independente da língua-meta, nem há língua-meta que independa da língua-fonte. Em outros termos, não há uma dualidade ontológica e temporal entre os dois níveis: os processos secundários só existem graças à tradução de processos primários e, no outro sentido, os pensamentos latentes aos que chega a interpretação só existem através dessa interpretação. A consequência disso me parece importante aqui. Quando a representação de palavra, tornada inconsciente, é tratada pela psique como uma representação de coisa, como vimos nas associações interlinguísticas, não se trata mais de palavra, mas de um material novo criado pela plasticidade dos processos primários.

Portanto, se a confrontação dos migrantes com uma língua estrangeira atua na formação ou na resolução dos sintomas, não é como língua, mas como novas entidades, novos significantes tomados em redes inconscientes, como qualquer outra especificidade do país de acolhimento que se torna significante - a expressão de um rosto, um incidente administrativo, um novo hábito culinário etc. Entretanto, essa clínica com poliglotas e multilíngues tem a ver com a tradução no outro sentido de Uberträgung: a transferência.

\section{A tradução transferencial}

A transferência poderia ser entendida como uma tradução interlinguística, no sentido em que Benjamin (2000) define a tradução. Na sua visão histórica, inspirada no messianismo, Benjamin (2000) considera que as línguas podem alargar-se 
mutuamente e domiciliar-se uma na outra. A mais específica tarefa humana, a do/a tradutor/a, e que poderíamos comparar à transferência, é reunir os fragmentos dispersos da língua pré-babélica ecoados por todas as línguas. O/A tradutor/a recorda e repara simbolicamente a catástrofe de uma originalidade despedaçada, mas nunca a restitui. Similarmente, o mecanismo de transferência entre dois poliglotas atualiza imaginariamente esse agrupamento de uma dispersão, sem nunca efetuá-lo simbolicamente. Lembremos que não há unidade e completude atualizada, senão como mito.

A questão do vínculo entre transferência e tradução é, em verdade, a questão do linguístico e do pré-linguístico, da continuidade entre corpo e linguagem, mundo fenomenológico e simbolização. Sem pretender abordar esta vasta questão aqui, assinalaria que o mundo não precede a língua, mas é sempre entendido a partir do horizonte da língua (o que provoca grandes tormentos aos tradutores!). Por exemplo, enquanto o francês ou o português dizem "Atravessaram o rio nadando", expressando o espaço pelo verbo principal e a natureza do movimento pelo gerúndio, o inglês inverte isso, dizendo "They swam accross the river", verbalizando a natureza do movimento e informando sobre o espaço por uma preposição. Similarmente, em françês "je suis en retard", temporal, corresponde ao inglês "I'm behind", espacial, ao espanhol "voy atrasado", móvel, ao catalão "vaig de cul", imaginário, ou ao marroquino مشى عليا الحال 'ma alia el hal\} passivo (o tempo me abandonou).

Conceber a transferência como tradução é, então, considerar que a tradução é sempre "entre": nem unicamente na fonte, nem unicamente na meta. Apreciada como espaço do "entre", a transferência procede de uma abordagem da intersubjetividade. Não se trata aqui só da alteridade (em muitas línguas, o outro é somente uma figura definida a partir do sujeito: outro, otro, altre, altro, other, ander vêm de alter, o segundo termo de

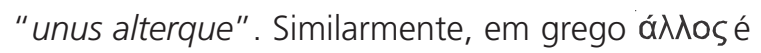
concebido em função de ópo , em árabe, غير [rair] é uma modificação do sujeito, e em hebraico אחר שני אמי מaher\} quer dizer o que segue, 106 o segundo. Ao contrário, é uma questão de intersubjetividade: o sujeito ou a consciência não são primeiros, mas resultam de uma relação, precedendo e determinando a subjetividade. O espaço transferencial seria então um espaço "entre" : entresujeitos, entre-línguas.

A transferência, que literal e etimologicamente significa transporte, torna-se assim metáfora (cuja etimologia é transporte, em grego). Na cura, a corporeidade tanto do/a analista quanto do/a analisando/a estão transportadas numa pluralidade de línguas, e a metáfora da transferência faz comunicar a palavra e o gesto.

É precisamente essa multiplicidade material da palavra, do gesto, do pensamento, não só linguísticos, que se transcreve em pluralidade de associações interlinguísticas, durante a sessão, e depois, durante a escritura narrativa da sessão. Para transcrever essa multiplicidade material fazem-se necessárias, às vezes, línguas plurais.

Mais concretamente, seria preciso que o/a analista de um/a paciente poliglota ou multilíngue seja, ele/a também, poliglota ou multilíngue? É certo que uma ou mais línguas comuns entre o/a analista e o/a analisando/a às vezes permitem ao/a primeiro/a encontrar os percursos do pensamento e as conexões significantes do/a segundo/a, como vimos. Mas isso não basta. Além disso, essas línguas comuns podem introduzir o/a analista na posição imaginária de onipotência e onisciência: ele/a assim não assumiria a limitação necessária da sua ilusão de compreender, para poder escutar o/a analisando/a. Isso poderia mesmo dar lugar à fantasia antebabélica de uma língua originária, de uma comunicação total, unitária.

Igualmente, para o/a analisando/a, uma segunda língua em comum com o/a analista poderia dar origem a uma atitude de sedução e a fantasias de conivência ou de pertencer à mesma comunidade. O/A analista deve cuidar para que essa conivência não seja forte demais, e introduza uma ilusão de simetria e reciprocidade, reduzindo-o à posição imaginária de um semelhante. O poliglotismo tem limites: o uso de outra língua pode manifestar certa recusa de comunicar por parte do/a paciente, e demonstrar onipotência por parte do/a analista. 
Outrossim, não se deve confundir a divisão subjetiva do/a paciente com a dicotomia imaginária de não saber se pertence mais a uma cultura ou a outra.

Portanto, o poliglotismo pode ajudar no trabalho terapêutico só no sentido de que essa língua antebabélica da transferência nunca é atualizada, mas ressoa como um original perdido para sempre, um mito heurístico de espaço "entre", impossível de realizar, sempre incoativo, sempre em transformação.

Única ou plural, uma língua contem numerosas vias associativas. Portanto, antes que a poliglossia, é a polifonia que se revela útil para o/a analista, favorecendo uma escuta de numerosos discursos, vias associativas e experiências. O significante na psicanálise não é só um significante linguístico. Ainda que a área do/a psicanalista seja estruturada pelos efeitos da linguagem, não é estruturada só por eles: a heterogeneidade da pessoalidade psíquica procede também de efeitos do corpo, da norma e da intersubjetividade. O discurso do inconsciente é polifônico, poligráfico, e não se reduz à linguagem.

O trabalho analítico tenta restituir ao discurso o seu polilogismo funcional, a sua plurivocidade dialógica. Com respeito a esse discurso polilógico, não há uma especificidade dos pacientes poliglotas ou multilíngues, salvo no fato de que, com a organização multilinguística deles, esse funcionamento polilógico se destaca com mais clareza. Nesse sentido, o trabalho com poliglotas e multilíngues pode favorecer a pluridimensionalidade da escuta analítica. No mesmo sentido, a transcrição posterior da sessão, a narração transferencial, ao se fazer em muitas línguas, tenta recapturar essa dimensão poligráfica.
Concluamos assim que a mobilidade psíquica e a criatividade da linguagem provêm só de uma mistura, uma constante contaminação entre línguas, como aquela mescla presente na poesia dos trovadores da Idade Média, que circulavam entre várias culturas. Trovador vem do árabe \{tarab addour\}, literalmente "a alegria do giro e do estribilho que gira na música". Os trovadores foram filhos do طرب \{tarab\}, a música e a poesia refinada. As mães deles eram criadas estrangeiras, escravas que compartilhavam o leito dos generais árabes, rainhas do طرب \{tarab\}. Essas belas estrangeiras tinham filhos meio-árabes e meio-estrangeiros, aos quais falavam com língua estrangeira, erros e poesia. Em árabe, a mesma palavra لحن \{lahn\} designa a incorreção gramatical e a melodia. E essas melodias erradas giravam nas cortes e nos salões dos estetas. Girar. الدور \{addour\}, \{tarab addour\}, trovador. Cabe desejar aqui que a escuta analítica tenha orelha musical!

\section{Referências}

Abraham N., \& Torok M. (1999). Le Verbier de l'homme aux loups. Paris: Gallimard.

Amati Mehler, J. (2003). La migration, la perte et la mémoire. Etudes de linguistique appliquée, 131, 329-342.

Benjamin, W. (2000). La tâche du traducteur. In W. Benjamin Oeuvres I. Paris: Gallimard.

Freud, S. (1968). L'inconscient. In S. Freud, Métapsychologie. Paris: Gallimard. (Initialement public in 1915).

Hassoun, J. (1993). L'Exil de la langue. Paris: Point hors ligne.

Recebido: junho 12, 2013

Versão final: dezembro 18, 2013

Aprovado: janeiro 30, 2014 
